\title{
Functional and sustainable local self-government in the Croatian National Recovery and Resilience Plan 2021-2026
}

Ott, Katarina

Source / Izvornik: IPF Notes, 2021, 14, 1 - 11

Journal article, Published version

Rad u časopisu, Objavljena verzija rada (izdavačev PDF)

https://doi.org/10.3326/in.2021.121

Permanent link / Trajna poveznica: https:/urn.nsk.hr/urn:nbn:hr:242:081824

Rights / Prava: Attribution 4.0 International/Imenovanje 4.0 međunarodna

Download date / Datum preuzimanja: 2023-04-26

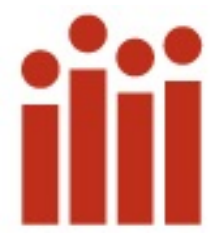

Repository / Repozitorij:

Institute of Public Finance Repository

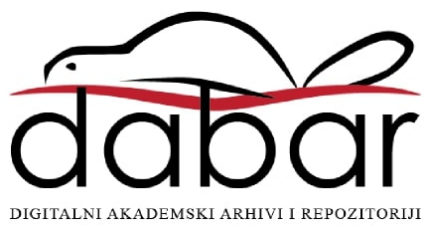



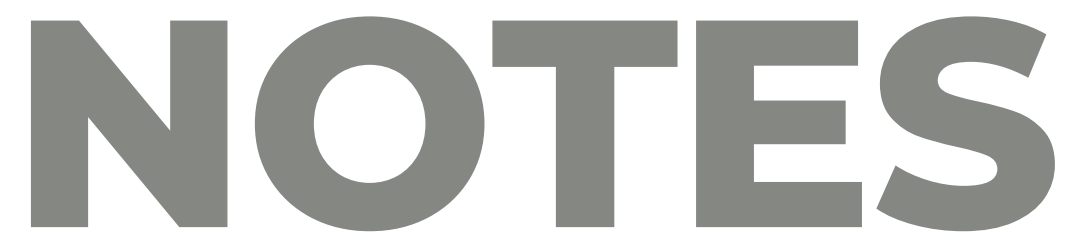

\title{
Functional and sustainable local self-government in the Croatian National Recovery and Resilience Plan 2021-2026
}

\author{
Katarina Ott \\ Institute of Public Finance, Zagreb
}

The Croatian Government designed a recovery plan for the country, which also includes incentivising the merger of local government administrations. The European Union (EU) endorsed the plan and is ready to provide funding. The Plan is a welcome addition in a country divided into too many local government units, some of them with extremely low population and very low income; it is a wonder why they have not been functionally and physically merged by now. Similar plans and projects have been proposed in the past, but with little result. Learning from previous experience, it is necessary to urgently define what the current Plan lacks specific deadlines for implementing all planned sub-stages and services. One would hope that this task would be on top of the 
ministries' and other state administration bodies' agenda and that they, in collaboration with local government units and other competent stakeholders, would do anything in their power not only for withdrawing the available funds but also for their efficient usage. This is the only way for this Plan to contribute to us finally living in a country with functional and sustainable local selfgovernment.

The Council of the European Union, as part of the Recovery and Resilience Facility, approved Croatia's National Recovery and Resilience Plan 2021-2026 (hereinafter: Plan) with a budget of EUR 6.3 billion, whereby Croatia is entitled to receive an advance payment of HRK 6.1 billion, or 13\% of the total grant, by end-2021. Needless to say, disbursement of funds will depend on the performance indicators defined in the Plan. For this reason, the Government assigned all competent bodies with the task of intensifying their work on the implementation of activities set out in the Plan.

The Plan defines, as one of the prerequisites for implementation and utilization of the provided funds, increasing state efficiency for materialising EU-funded reforms and projects and provides for, inter alia, further decentralization of the state and stimulating functional merging of local government units. The section "Public administration, judiciary and state property" provides for further enhancement of public administration efficiency; the reforms

\footnotetext{
'This note has originated from the project "Does Transparency Pay-off? The political and socio-economic impacts of local budget transparency in Croatia" (IP-2019-04-8360) financed by the Croatian Science Foundation (HRZZ).
} 
therein include functional and sustainable local self-government and expected investments for further optimization and decentralization by stimulating functional merging of local government units.

\section{Reforms for functional and sustainable local self-government}

Current quality of services provided by local self-government units is low, their administrative and fiscal capacity is poor as well as their transparency. The objective of functional integration of local government units is to establish efficient, high-quality and transparent services which would be able to meet the needs and interests of all citizens regardless of where they live.

The Plan provides for the establishment of a system for financing joint implementation of specific activities. Such cooperation of local government units would solve the problems of undercapacity, enhance their services and efficiency of utilization of funds. An interdepartmental working group would be formed, comprising experts from state administration bodies that would support the interested local government units. The Plan also provides for amendments to the legislative framework and the establishment of a financial support mechanism for stimulating functional and physical merging.

The implementation holders are the Ministry of Justice and Public Administration and the Ministry of Finance in cooperation with state administration bodies. The target group are local selfgovernment units, while the end beneficiaries include citizens and business entities. The estimated budget stands at HRK 21.6 million, while the implementation period is between December 2021 and 
June 2025. When compared to many other items set out in the Plan, this is a relatively low amount, but it is far from negligible. Therefore, we should seek to make maximum use of these funds.

\section{Optimization and decentralization by stimulating functional merging}

Due to poor administrative and fiscal capacity for providing highquality services, which causes citizens' dissatisfaction, the objective is to establish a system for functional and physical integration so that citizens could be provided with high-quality and transparent services while local government units would enhance their capacities for conducting activities more efficiently.

Stages and sub-stages of implementation have been defined as well as the services requiring funding; however, deadlines have been defined only for the stages but not for the sub-stages or the required services. An overview is provided at the end of the text. For example, we are not provided with the information when the selfassessment questionnaire will be drafted, or the concept design and functional specifications of the merger support system or the diagnostic report. We also do not know anything about the timeframe of the field survey of citizens or the awareness raising activity regarding the functional merger.

Even if we consider December 2021 a realistic deadline for adjusting regulations and March 2022 for activating the mechanism, awaiting guidelines/recommendations until December 2023 and establishing the entire system until June 2025 is a cause for concern, especially since deadlines for all sub-stages and services have not been defined. In all honesty, there is a reference to a potential mid-term 
evaluation in 2024 within the "National Development Plan for Public Administration 2021-2027" (under construction); however, for the purpose of monitoring, controlling and potentially correcting the implementation of the Plan, this is too late, especially keeping in mind that the National Development Plan for Public Administration is still being drafted and that the decision on its construction has been adopted by the Government fairly recently (8 April 2021).

An additional reason for concern is the fact that the Plan makes several references to the results of the Ministry of Public Administration's project "Optimization of the Local and Regional Self-government System", which would serve as the basis for implementation. The fact that the reform is not another fresh start but rather that it intends to use results of previous projects is definitely a plus; however, what do we know about this previous project? The Ministry of Public Administration's website states that this project was implemented in the period from 11 December 2018 to 11 December 2020 with a budget of HRK 20.1 million; its objective was to "improve the efficiency of public administration through the optimization of the local and regional self-government system, which would result in higher quality of public services provided to citizens at local and regional self-government units". This information leads to the conclusion that this project should have been completed by now, but official information in this regard is missing. Since the implementation of the Plan relies on this project, which should have been completed by now, the public should be made familiar with its results. The two projects are similar both in content and their financial weight (HRK 21.6 million as opposed to 20.1 million). 
Since one of the Plan's objectives is to increase the transparency of the local and regional self-government system, this can only be achieved through greater transparency of the central government system. All of this calls for urgent publication of the results of the optimization project above as well as of deadlines set for all substages and services provided for in the Plan. In addition, adherence to the deadlines should be regularly monitored, while results of this monitoring as well as results of all sub-stages and services should be published.

The Plan itself is quite a lengthy document spanning 1,273 pages, which will probably double once supporting documents are attached. It is therefore hard to expect a large number of readers to find their way around the document, even if they focus only on specific sections of the Plan. An even greater issue is whether the document will be accessible to those who are most affected by it the target group (local self-government units) and end beneficiaries (citizens and business entities), especially those in the smallest local government units that could benefit the most from proper implementation of the Plan. Positive aspects of the Plan include field surveys, educational sessions and similar activities, all of which require proper planning at early stages with specific deadlines and tasks. Another positive aspect is the establishment of interdepartmental groups, which are essential for such plans and projects; however, in order to brief and educate both the target group and end beneficiaries better, other stakeholders should be involved too, such as the Croatian County Association, Cities Association and the Croatian Municipality Association, all of which are well acquainted with the problems and abilities of the target groups. 
With this in mind, it is a priority to draft a clear, simple and practical guide - a manual of some sort - that would provide information about the Plan and the possibilities it offers to local government units; this manual should be used for raising awareness, briefing and engaging target groups (both executive and representative authorities of counties, cities and municipalities), end beneficiaries (citizens, citizens' associations, business entities) and the media (especially local media) into the process of functional and physical merging of units.

Through such well-designed and timely action, the dissatisfaction of citizens with the functioning and services of local government units, as well as the dissatisfaction of local government units themselves with their financial and administrative capacities, could be targeted toward their more active involvement in solving problems affecting them, some of which cannot be solved by even the largest units, let alone smaller ones, such as: waste collection and disposal, local and regional public transport, care of the elderly and disabled persons etc. This would also contribute to more efficient utilization of funds from other EU sources (which is one of the key objectives of the Plan) and could also contribute to UN Sustainable Development Goals (also referred to in the Plan).

Functional and physical merging is more than necessary in a country with such a large number of local government units, with around fifty municipalities with a population below 1,000, with drastic differences between units, not only in terms of population (with the smallest municipality counting 137 residents and the largest as many as 16,500) but also in terms of per capita income (ranging from HRK 1,700 to 27,000) (see IPF, 2020). And it would be incorrect to say that they are not prepared to change and improve. 
As a result of the Institute of Public Finance's activities funded by the Ministry of Finance, the average budget transparency of all local government units improved from 1.8 to 4.5 between 2015 and 2021 . For instance, in 2015 only 1\% of municipalities published their citizens' budget, while 2021 saw as many as $80 \%$ of municipalities publishing their citizens' budgets (see IPF, 2021). Provision of information, topic promotion, stimulation, amendments to legislation and regulation - all of this should lead to changes.

In short, the Plan deserves praise since both functional and physical merger is a must. However, learning from previous similar plans and projects that never came to life, implementation holders should do the following right from the start:

- define specific deadlines and implementation monitoring system,

- create proper guides, manuals and instructions for briefing target groups and beneficiaries,

- engage representatives of the Croatian County Association, Cities Association and the Croatian Municipality Association, academic community, local associations and media, primarily at the initial stages but also throughout the Plan's implementation period.

All of this could highly contribute to the efforts of the implementation holders (Ministry of Justice and Public Administration, Ministry of Finance and other public administration bodies engaged in the Plan), who would be unable to implement on their own, i.e., without collaborators "on the ground", an idea that has been a hot topic for decades but has never been implemented in full. We were given another opportunity, and this time it should be properly used. 


\section{APPENDIX}

\section{Further optimization and decentralization by stimulating functional merging of local government units}

\section{Stages}

- Adjustment of regulations pertaining to fiscal incentives for voluntary integration of units (December 2021)

- Activating the basic (fiscal) support mechanism for voluntary functional and physical integration of units (March 2022)

- Drafting guidelines/recommendations for joint execution of specific activities and physical merging of units based on good practice in the EU (December 2023)

- Establishing an integral system of support to functional and physical integration of units (June 2025)

\section{Sub-stages}

- Creating questionnaires for units to self-assess their current capacity for conducting activities within their scope of work and express their needs and interests for joint execution of activities, i.e. physical merger

- Identifying the state of affairs regarding the execution of activities within the units' scope of work, using an IT system, catalogue and categories defined within the project Optimization of the Local and Regional Self-government System

- Drafting a concept design and functional specifications of the System for supporting physical and functional integration of units

- Drafting a model for functional integration of units and establishing additional financial incentives for physical mergers

- Identifying units which would benefit from functional mergers and activities that they could execute together

- Identifying units which would benefit from physical mergers

- Developing and implementing the System for supporting physical and functional integration of local self-government units (architectural and programme design, developing the System modules, implementing the system to CDU's infrastructure, testing and creating user and technical documentation for the System) 
- Upgrading to the IT system of the Optimization of Local and Regional Selfgovernment project

- Implementing a pilot project of functional integration and physical merging

- Educating public administration officers that would support the officials in the units concerned regarding the functional integration and physical merging

- Providing digital and direct support to officials in the units concerned that conduct joint operations or plan to physically merge

- Educating officials in the units concerned for working in the System.

\section{Services to be funded from the estimated budget}

1) Consultancy services for:

- Diagnostic report on the legal and institutional framework for functional merging of units in Croatia, including an overview of implementation results for similar reforms in EU Member States

- Conducting a field survey of citizens pertaining to functional mergers of units examination and analysis of public service users' abilities and needs for integrated functions

- Developing a model for voluntary mergers with compensation mechanisms

- Implementation strategy and change management with a cost-and-benefit analysis

- Raising awareness on functional merging of units

- Preparing and implementing education programmes for public servants, accompanied by the development of e-learning materials, educating 50 state administration officials for providing support to local self-government units pertaining to functional integration and physical merging and educating 100 local administration officials for conducting joint activities as part of functional integration

- Evaluation of implemented process in terms of efficiency, citizens' satisfaction and trust and adjustment recommendations

- Mid-term evaluation of the National Development Plan for Public Administration 2021-2027

- Creating functional tasks for the IT support system for functional merging based on the model.

2) Establishing the IT system and software support to functional and physical integration of local government units - architectural and programme design, developing system modules, implementing the system to CDU's infrastructure, testing and creating user manuals, preparing and implementing education programmes accompanied by the development of e-learning materials 
3) Communication and introduction of innovative (digital) mechanisms for citizens' participation in the implementation of the National Development Plan for Public Administration 2021-2027

4) Project management

Source: National Recovery and Resilience Plan, pp. 545-546. 